\section{Viticultural Performance of Red and White Wine Grape Cultivars in Southwestern Idaho}

\author{
Krista C. Shellie ${ }^{1}$
}

ADDITIONAL INDEX WORDS. grapevine, phenology, heat accumulation, germplasm, Vitis vinifera

SUMMARY. A collection of 23 red and six white wine grape (Vitis vinifera) cultivars were evaluated for viticultural performance in Parma, ID. Vine yield, fruit composition, and vegetative growth were measured over four growing seasons, and data were used to compare relative cultivar performance based on yield to pruning ratio and fruit maturity. Relative differences among cultivars in budbreak day of year [96 (6 Apr.) to 122 ( 2 May)] and days from budbreak to harvest (143 to 179 days) varied from year to year. The earliest and latest maturing cultivars in 3 of 4 years were 'Blauer Portugieser' (143 days), 'Nebbiolo' (177 days), 'Barbera' (179 days), 'Orange Muscat' (144 days), 'Flora' (149 days), 'Muscat of Alexandria' (166 days), and 'Viognier' (168 days). Cultivars differed in yield (2.4 to 7.0 tons/acre), vegetative vigor (4.6 to 20.4 yield/pruning weight), and harvest soluble solids concentration (21.1 to 26.5), but differences in harvest $\mathrm{pH}(3.0$ to 4.1$)$ and titratable acidity $\left(2.48\right.$ to $\left.13.03 \mathrm{~g} \cdot \mathrm{L}^{-1}\right)$ varied from year to year. Average heat unit accumulation (1646) was 160 units higher than the 78-year site average. Few (less than 150) units accumulated in April and October, most units accumulated in July, and diurnal difference in air temperature was $\approx 15^{\circ} \mathrm{C}$. Performance results from this study can assist cultivar site selection by comparing climate data for an intended site with that of Parma. For example, the low acidity and earliness of 'Blauer Portugieser' suggests it is best suited to a site with less heat unit accumulation than Parma, and the high acidity and late maturity of 'Barbera', 'Nebbiolo', and 'Carignan' suggest these cultivars are best suited to a site with more heat unit accumulation than Parma. The inconsistent relationship between onset of budbreak and earliness observed in this study suggests opportunity to match short-season cultivars late to break bud such as Flora to short-season growing sites prone to late-season frost.

$\mathrm{N}$ ew vineyard regions are being tested and established throughout North America in climatic zones once considered marginal or unsuitable for growing grapes of European origin (Vitis vinifera) for wine production (Evans et al., 2005; Hamman, 1993; Kaps and Odneal, 2001; Reynolds et al., 2004; Wolf and Warren, 2000). Acreage expansion into marginal areas is driven by the potentially high economic value of associated agribusiness and tourism as well as the high production efficiency of wine grapes relative to other traditional agricultural products. Determination of suitability

U.S. Dept. of Agriculture, Agricultural Research Service, Horticultural Crops Research Laboratory, 29603 U of I Lane, Parma, ID 83660

I thank the Idaho Grape Growers and Wine Producers and Essie Fallahi for planting the material evaluated in this study and Jeff Acock, Chris Rennaker, David Straley, Josh Gregersen, and Mark Redhead for their technical assistance.

Mention of a trademark, proprietary product, or vendor does not constitute a guarantee or warranty of the product by the U.S. Dept. of Agriculture and does not imply its approval to the exclusion of other products or vendors that also may be suitable.

${ }^{1}$ E-mail: kshellie@uidaho.edu. for cultivation of wine grapes based on cold events or disease prevalence is more easily accomplished than matching of cultivars to particular mesoclimates, yet districts of origin in well-established production regions demonstrate the importance of cultivar site selection. When the California wine industry began growth in the late 1800 s, information from Old World wine-producing countries provided limited assistance for determining cultivar suitability. After 50 years of extensive cultivar testing conducted in California under varied environmental conditions, a climate classification system based on heat unit accumulation was developed to compare and describe production regions (Winkler et al., 1974). Cultivar site evaluation also played an important role in Washington state wine industry growth where cultivar trials were initiated in 1937 and continued into the late 1980s (Ahmedullah, 1985; Clore et al., 1976; Nagel and Spayd, 1990; Powers et al., 1992).

The uniqueness of Idaho's viticultural climate and youth of its industry warrant evaluation of cultivar suitability for commercial production (fruit quality and quantity sufficient to be competitive). Idaho's principal wine grape-growing district is located in the western half of the Snake River Plain, a crescent-shaped depression that stretches roughly $600 \mathrm{~km}$ across southern Idaho. The arid, continental climate of the western Snake River Plain is similar to other warm, arid grape-growing regions in eastern Washington, northern Nevada, western Colorado, and south central British Columbia, Canada, where the growing season is delimited by spring or fall frost events. In addition to macroclimate, the diverse topography within the grape-growing region creates distinct mesoclimates that greatly impact cultivar suitability. The large mesoclimate diversity offers opportunities, but also poses additional challenges for cultivar site selection.

Wine grapes are Idaho's second largest fruit crop [U.S. Dept. Agr. (USDA), 2007]. Acreage doubled between 1993 and 1998 to 647 acres in 27 vineyards, and the most recent tree fruit census reported 1215 acres in 49 vineyard operations. Cultivar selection appears historically based on a perceived need for cold

\begin{tabular}{lllc}
\hline $\begin{array}{l}\text { Units } \\
\text { To convert U.S. to SI, } \\
\text { multiply by }\end{array}$ & U.S. unit & SI unit & $\begin{array}{l}\text { To convert SI to U.S., } \\
\text { multiply by }\end{array}$ \\
\hline 0.4047 & acre $(\mathrm{s})$ & $\mathrm{ha}$ & 2.4711 \\
29.5735 & $\mathrm{fl} \mathrm{oz}$ & $\mathrm{mL}$ & 0.0338 \\
0.3048 & $\mathrm{ft}$ & $\mathrm{m}$ & 3.2808 \\
3.7854 & $\mathrm{gal}$ & $\mathrm{L}$ & 0.2642 \\
2.5400 & inch $(\mathrm{es})$ & $\mathrm{cm}$ & 0.3937 \\
0.4536 & $\mathrm{lb}$ & $\mathrm{kg}$ & 2.2046 \\
1.6093 & $\mathrm{mile}(\mathrm{s})$ & $\mathrm{km}$ & 0.6214 \\
28.3495 & $\mathrm{oz}$ & $\mathrm{g}$ & 0.0353 \\
0.001 & $\mathrm{ppm}$ & $\mathrm{g} \cdot \mathrm{L}^{-1}$ & 1000 \\
2.2417 & $\mathrm{ton} / \mathrm{acre}$ & $\mathrm{mg} \cdot \mathrm{ha}^{-1}$ & 0.4461 \\
$\left({ }^{\circ} \mathrm{F}-32\right) \div 1.8$ & ${ }^{\circ} \mathrm{F}$ & ${ }^{\circ} \mathrm{C}$ & $\left(1.8 \times{ }^{\circ} \mathrm{C}\right)+32$ \\
& & & \\
\hline
\end{tabular}


hardiness and low heat unit requirement because an estimated $60 \%$ of acreage is comprised of cool season, cold-hardy white wine cultivars ['Riesling', 'Chardonnay', and 'Gewurztraminer' (Gillerman et al., 2006)]. More recent plantings include the red cultivars 'Cabernet Sauvignon', 'Merlot', and 'Syrah', demonstrating industry interest in expanding cultivar selection. Despite the growing importance of wine grapes in Idaho's economy, little published information is available on cultivar performance under Idaho growing conditions. The objective of this study was to compare the viticultural performance of red and white wine grape cultivars under similar cultural practices to assist cultivar site selection for future plantings.

\section{Materials and methods}

All of the cultivars evaluated in this study have a history of commercial production in well-established viticulture regions but have either never or only recently been planted in southwestern Idaho. A description of each cultivar with its corresponding major area of production is presented in Table 1 . The cultivars were planted on their own roots in 1997 (Fallahi et al., 2004) or 1998 (Fallahi et al., 2005) with planting material purchased through Foundation Plant Services, Davis, CA. Clonal designations are those used by Foundation Plant Services. The cultivars were evaluated at the University of Idaho Parma Research and Extension Center (lat. $43^{\circ} 47^{\prime} \mathrm{N}$, long. $116^{\circ} 57^{\prime} \mathrm{W}$, elevation $750 \mathrm{~m}$ ) in Parma, ID. Average annual precipitation for Parma is 9.7 inches of which $45 \%$ falls during the growing season (1 Apr. through 31 Oct.) and provides $10 \%$ of pan evapotranspiration (U.S. Dept. Interior, 2006). Climate data (19222005 ) indicates a $90 \%$ probability of a freeze $\left(-1.46^{\circ} \mathrm{C}\right)$ event after $1 \mathrm{Apr}$, dropping to $20 \%$ by 1 May (USDA, 1972). The soil at the trial site was a Turbyfill, fine sandy loam with a $\mathrm{pH}$ of 7.9 in the top 12 inches and $0.9 \%$ organic matter. Eight vines of each cultivar were planted next to one another. The vine groups were planted in a completely randomized fashion within four field replications. The vines were spaced $7 \mathrm{ft}$ apart in north-south-oriented rows that were
Table 1. Region of major production for red and white wine grape cultivars evaluated on their own roots in Parma, ID.

\begin{tabular}{|c|c|c|c|}
\hline Cultivar (clone no.) & Acronym & Major acreage & Region $^{\mathrm{y}}$ \\
\hline \multicolumn{4}{|l|}{ Red skin } \\
\hline Barbera $(02)$ & BA & Italy ${ }^{x}$ & Piemonte \\
\hline Blauer Portugieser (02) & $\mathrm{BP}$ & Germany/Austria & Pfalz/Vienna \\
\hline Cabernet Franc $(04)$ & $\mathrm{CF}$ & France $^{\mathrm{x}}$ & Bordeaux \\
\hline Cabernet Sauvignon (04) & CS & France $^{\mathrm{x}}$ & Bordeaux \\
\hline Carignan $(06)$ & CG & France $^{x}$ & Midi \\
\hline Dolcetto $(01)$ & DL & Italy & Piemonte \\
\hline Grenache $(03)$ & GR & Spain $^{x}$ & Rioja \\
\hline Lemberger $(02)$ & LE & Germany ${ }^{x}$ & Wurttemberg \\
\hline Malbec (06) & MA & Argentina $^{\mathrm{x}}$ & Mendoza \\
\hline Merlot (08) & $\mathrm{ME}$ & France $^{\mathrm{x}}$ & Bordeaux \\
\hline Pinot Meunier (01) & $\mathrm{MN}$ & France $^{x}$ & Champagne \\
\hline Nebbiolo (01) & NB & Italy & Piemonte \\
\hline Petit Verdot $(01)$ & PV & France & Bordeaux \\
\hline Petite Sirah (03) & PS & California & California \\
\hline Pinot Noir (18) & $\mathrm{PN}$ & France $^{x}$ & Burgundy \\
\hline Pinotage $(01)$ & PT & South Africa & Stellenbosch \\
\hline Primitivo $(03)$ & PR & Italy & Puglia \\
\hline Sangiovese (04) & SG & Italy $^{x}$ & Chianti \\
\hline Souzao $(01)$ & SZ & Portugal & Douro \\
\hline Syrah $(07)$ & SY & France $^{\mathrm{x}}$ & Rhone \\
\hline Touriga Nacional (02) & TG & Portugal & Douro \\
\hline Valdepenas $(03)$ & VP & Spain $^{x}$ & Rioja \\
\hline Zinfandel (03) & $\mathrm{ZN}$ & U.S. ${ }^{x}$ & California \\
\hline \multicolumn{4}{|l|}{ White skin } \\
\hline Chardonnay (38) & $\mathrm{CH}$ & U.S. ${ }^{x}$ & California \\
\hline Flora $(04)$ & FL & U.S. & California \\
\hline Muscat of Alexandria (02) & MU & Spain $^{x}$ & Alicante \\
\hline Orange Muscat (01) & $\mathrm{OM}$ & U.S. & California \\
\hline Pinot Gris $(04)$ & PG & Italy $^{x}$ & Lombardy \\
\hline Viognier $(01)$ & VI & France & Rhone \\
\hline
\end{tabular}

${ }^{\mathrm{z}} \mathrm{Fegan}, 2003$.

yohnson, 1994.

'One of the world's 81 most widely planted grape cultivars (Fegan, 2003).

Table 2. Growing degree days and average daily maximum and minimum air temperature at the University of Idaho Parma Experiment Station in Parma, ID.

\begin{tabular}{|c|c|c|c|c|c|}
\hline & \multicolumn{5}{|c|}{ Growing degree days } \\
\hline & 2002 & 2003 & 2004 & 2005 & $1922-2005^{z}$ \\
\hline \multicolumn{6}{|c|}{ Growing degree days ${ }^{y}$} \\
\hline April & 36.0 & 41.3 & 82.2 & 45.8 & 35.5 \\
\hline May & 151.4 & 168.7 & 149.5 & 158.5 & 139.9 \\
\hline June & 305.6 & 329.3 & 298.5 & 222.7 & 245.3 \\
\hline July & 465.9 & 503.5 & 434.4 & 431.4 & 383.5 \\
\hline August & 346.9 & 427.1 & 395.5 & 410.6 & 350.2 \\
\hline September & 227.2 & 247.8 & 200.2 & 194.3 & 180.4 \\
\hline October & 46.9 & 133.5 & 83.8 & 47.3 & 35.5 \\
\hline Season & 1579.9 & 1851.2 & 1644.1 & 1510.6 & 1486.8 \\
\hline \multicolumn{6}{|c|}{ Avg daily maximum temp $\left({ }^{\circ} \mathrm{C}\right)^{\mathrm{x}}$} \\
\hline July & 35.9 & 36.1 & 34.2 & 33.7 & 33.4 \\
\hline August & 31.0 & 33.7 & 32.8 & 33.7 & 32.5 \\
\hline September & 28.5 & 27.9 & 26.1 & 26.1 & 26.8 \\
\hline \multicolumn{6}{|c|}{ Avg daily minimum temp $\left({ }^{\circ} \mathrm{C}\right)$} \\
\hline July & 14.6 & 16.0 & 14.1 & 13.2 & 12.6 \\
\hline August & 10.9 & 13.7 & 13.3 & 12.6 & 11.2 \\
\hline September & 7.9 & 7.9 & 7.4 & 5.9 & 6.2 \\
\hline
\end{tabular}

${ }^{\mathrm{z}}$ Desert Research Institute, 2006.

ySimple daily average 1 Apr. to 31 Oct. using a base of $10^{\circ} \mathrm{C}\left(50.0^{\circ} \mathrm{F}\right)$ with no upper limit (The Northwest Berry and Grape Information Network, 2004).

${ }^{\mathrm{x}}\left(1.8 \times{ }^{\circ} \mathrm{C}\right)+32={ }^{\circ} \mathrm{F}$ 
$9 \mathrm{ft}$ wide. Vines were trained as two trunks, each with a unilateral cordon located 40 inches above the soil surface. Cordons were spur-pruned each year and shoots were positioned vertically upright with the aid of trellis foliage wires.

Vineyard and vine management was according to commercial recommendations for eastern Washington (Watson, 1999) and included early season mowing of a cereal rye (Secale cereale) cover crop between rows and periodic spot application of in-row herbicide for weed control. Conventional fungicide applications were made throughout the season for control of powdery mildew (Uncinula necator), and insecticides were applied as needed. The vines were irrigated twice weekly using drip tubing suspended from the lower trellis wire $\approx 18$ inches above the soil surface; $1 \mathrm{gal} / \mathrm{h}$ punch-in emitters were located $\approx 6$ inches on either side of the vine. Vine management consisted of shoot thinning to an average of 15 shoots per meter of canopy shortly after budbreak and shoot positioning and hedging as needed to maintain an average shoot length of $1.2 \mathrm{~m}$. Dormant canes were annually pruned to an average of eight spurs per meter with two-bud spurs on red and threebud spurs on white cultivars.

Data collected each season included dates of major phenological events, yield components and fruit chemistry at harvest, and cane pruning weights. The day of year for budbreak, bloom, and veraison was determined by visual inspection for stages 4,23 , and 35 using the modified E-L system (Coombe, 1995). Harvest date for each cultivar was based primarily on berry soluble solids concentration (SSC) and secondarily on titratable acidity (TA) and $\mathrm{pH}$. Target SSC was $24 \%$ for red and white cultivars. The target TA and $\mathrm{pH}$ for red and white cultivars, respectively, was 7 or $8 \mathrm{~g} \cdot \mathrm{L}^{-1}$ and 3.6 or 3.45. Data were collected from the middle vines within each group of eight vines. The number of clusters per vine was counted at harvest and yield per vine was used to calculate average cluster weight. Berry weight and must TA and SSC at harvest were measured from a sample of 10 clusters harvested equally from the east and west sides of the canopy. Berry weight was determined from a 100-berry subsample randomly selected from five locations (four cardinal quadrants and one center) on each cluster in the 10-cluster sample. The remaining berries in the 10-cluster sample were passed through a hand-operated crusher, filtered, and a $40-\mathrm{mL}$ must sample was used to measure SSC with a model RE40 temperature-compensating re-

fractometer (Mettler-Toledo, Columbus, $\mathrm{OH}$ ). Juice $\mathrm{pH}$ was measured before titration as described by Shellie (2006). Determination of maturity for harvest was based on repeated analyses of a 10-cluster sample from nondata vines. The multiseason data were analyzed separately for each skin color using SAS GLM procedure

Table 3. Budbreak day of year for red and white wine grape cultivars at Parma, ID. ${ }^{\mathrm{z}}$

\begin{tabular}{|c|c|c|c|c|c|}
\hline \multirow[b]{2}{*}{ Cultivar $^{\mathrm{y}}$} & \multicolumn{5}{|c|}{ Bud break (day of yr) } \\
\hline & Avg 2002-2005 & 2002 & 2003 & 2004 & 2005 \\
\hline \multicolumn{6}{|l|}{ Red skin } \\
\hline Nebbiolo & 106.0 & 109.0 & 105.4 & 96.5 & 113.3 \\
\hline Sangiovese & 106.3 & 107.3 & 108.0 & 96.0 & 114.1 \\
\hline Grenache & 106.7 & 109.0 & 105.9 & 96.8 & 115.0 \\
\hline Cabernet Franc & 107.2 & 109.0 & 106.9 & 98.0 & 115.0 \\
\hline Pinotage & 107.3 & 109.0 & 105.8 & 100.3 & 114.1 \\
\hline Lemberger & 107.3 & 109.0 & 105.6 & 97.8 & 116.8 \\
\hline Merlot & 107.4 & 109.0 & 108.2 & 97.3 & 115.0 \\
\hline Barbera & 107.5 & 110.6 & 106.3 & 98.3 & 115.0 \\
\hline Blauer Portugieser & 107.9 & 110.6 & 106.3 & 99.3 & 115.0 \\
\hline Malbec & 108.2 & 109.0 & 109.1 & 100.5 & 114.1 \\
\hline Syrah & 108.5 & 110.6 & 108.8 & 99.5 & 115.0 \\
\hline Touriga Nacional & 108.8 & 109.0 & 110.5 & 100.8 & 115.0 \\
\hline Zinfandel & 108.9 & 109.0 & 110.0 & 99.8 & 116.8 \\
\hline Pinot Noir & 109.6 & 113.7 & 109.4 & 101.1 & 114.0 \\
\hline Valdepenas & 110.4 & 109.0 & 109.1 & 101.5 & 122.0 \\
\hline Souzao & 110.4 & 109.0 & 112.8 & 100.4 & 119.4 \\
\hline Petit Verdot & 110.7 & 109.0 & 111.1 & 104.0 & 118.5 \\
\hline Petite Sirah & 111.0 & 114.5 & 111.5 & 99.5 & 119.4 \\
\hline Primitivo & 111.2 & 118.0 & 111.5 & 99.3 & 115.9 \\
\hline Carignan & 111.4 & 115.5 & 107.5 & 103.8 & 119.4 \\
\hline Dolcetto & 111.7 & 112.4 & 110.0 & 102.3 & 122.0 \\
\hline Cabernet Sauvignon & 111.9 & 109.0 & 114.3 & 104.0 & 120.3 \\
\hline Pinot Meunier & 114.6 & 122.0 & 112.9 & 103.1 & 120.3 \\
\hline Avg & 109.2 & 111.0 & 109.0 & 100.0 & 116.7 \\
\hline $\operatorname{MSD}^{x}$ & & 8.1 & 3.8 & 2.1 & 3.9 \\
\hline \multicolumn{6}{|l|}{ White skin } \\
\hline Orange Muscat & 104.9 & $n e^{w}$ & 104.3 & 97.3 & 113.3 \\
\hline Chardonnay & 106.5 & 111.6 & 102.5 & 97.0 & 115.0 \\
\hline Muscat of Alexandria & 108.3 & 109.0 & 107.8 & 102.0 & 113.6 \\
\hline Viognier & 109.0 & 111.5 & 111.4 & 98.0 & 115.0 \\
\hline Pinot Gris & 110.7 & 110.6 & 111.9 & 100.8 & 119.4 \\
\hline Flora & 113.2 & 122.0 & 111.8 & 100.8 & 119.4 \\
\hline Avg & 108.8 & 113.0 & 108.3 & 99.3 & 115.9 \\
\hline MSD & & 9.1 & 2.4 & 4.2 & 6.7 \\
\hline \multicolumn{6}{|c|}{$P>F$} \\
\hline \multicolumn{6}{|l|}{ Red skin } \\
\hline Cultivar (CV) & $<0.0001$ & 0.0507 & 0.0171 & 0.0022 & 0.0448 \\
\hline Year $(\mathrm{Y})$ & $<0.0001$ & & & & \\
\hline $\mathrm{CV} \times \mathrm{Y}$ & 0.0441 & & & & \\
\hline \multicolumn{6}{|l|}{ White skin } \\
\hline Cultivar (CV) & 0.0036 & 0.3127 & 0.0101 & 0.6349 & 0.2043 \\
\hline Year $(\mathrm{Y})$ & $<0.0001$ & & & & \\
\hline $\mathrm{CV} \times \mathrm{Y}$ & 0.1417 & & & & \\
\hline
\end{tabular}

${ }^{\mathrm{z}}$ Cultivars within each skin type are listed in order of 2002-2005 average value.

${ }^{y}$ Clonal designations are listed in Table 1.

${ }^{\mathrm{x}}$ Minimum significant difference using Waller-Duncan k-ratio $\leq 0.05$.

we $=$ not evaluated. 
(SAS Institute, Cary, NC). Singleseason data were analyzed using the SAS GLM procedure with the minimum significant difference generated by Waller-Duncan k-ratio $t$ test. The calculated 4-year average ratios for fruit maturity (SSC and TA) and vine balance (yield to pruning weight ratio) for each cultivar were graphed as $\mathrm{X}, \mathrm{Y}$ pairs in a scattergram using SigmaPlot (SPSS, Chicago).

\section{Results and discussion}

The average (1922-2005) growing season heat unit accumulation (GDD) at the Parma site (Table 2) was within the upper range of California Climatic Region II (Winkler et al., 1974). Average heat unit accumulation was 160 GDDs higher than the 78 -year site average with 2 years (2003 and 2004) falling within the temperature range for California Climatic Region III. The coolest growing season was 2005 (1511 GDD) and the warmest was 2003 (1851 GDD). Early and midseason maturing cultivars are reported to require a minimum of 1500 GDD within a period of $\approx 150 \mathrm{~d}$ frost-free (Weaver, 1976). The frost-free period and heat unit accumulation at Parma during the years of this study exceeded these minimum values. The Parma growing site accumulated slightly more heat units than wine grape trial sites in Reno, NV (Evans et al., 2005), British Columbia, Canada (Reynolds et al., 2004), and Prosser, WA (Nagel and Spayd, 1990; Powers et al., 1992) but was less than Grand Junction, CO (Hamman, 1993 ) and Winchester, VA (Wolf and Warren, 2000). Despite higher seasonal heat unit accumulation in Winchester, VA, average onset of budbreak at Parma was $5 \mathrm{~d}$ earlier and $10 \mathrm{~d}$ shorter between budbreak and harvest (Wolf and Miller, 2001). The monthly pattern of heat unit accumulation in Grand Junction, $\mathrm{CO}$, and Prosser, WA, was similar to the trial site in this study in that few (less than 150) heat units accumulate in April and October, and maximum heat unit accumulation occurred during July. Other similar climatic features of growing sites in British Columbia, Nevada, Washington, and Colorado are low growing season precipitation, high evaporative demand, high solar radiation, and a large difference $(\approx 15$ ${ }^{\circ} \mathrm{C}$ ) in diurnal air temperature.
The timing of major phenological events (budbreak, bloom, veraison, and harvest) reflect genotype by environment interaction and impact cultivar site suitability because growing conditions at different stages of berry development uniquely impact fruit production and quality. The environmental conditions that induce release from dormancy are known to vary according to genotype, and in this study, a range of $26 \mathrm{~d}$ was observed among the cultivars. The 4-year average day of year (DOY) for budbreak was 109 (19 Apr.) and was earliest in 2004 (DOY 100) when heat unit accumulation was approximately twice the amount of other years (Table 2)

Table 4. Elapsed days from budbreak to harvest for red and white wine grape cultivars at Parma, ID. ${ }^{\mathrm{z}}$

\begin{tabular}{|c|c|c|c|c|c|}
\hline \multirow[b]{2}{*}{ Cultivar $^{\mathrm{y}}$} & \multicolumn{5}{|c|}{ Bud break to harvest (d) } \\
\hline & Avg 2002-2005 & 2002 & 2003 & 2004 & 2005 \\
\hline \multicolumn{6}{|l|}{ Red skin } \\
\hline Blauer Portugieser & 142.6 & 131.4 & 144.4 & 152.8 & 142.0 \\
\hline Pinot Meunier & 151.2 & 137.0 & 153.1 & 169.9 & 144.8 \\
\hline Dolcetto & 152.3 & 139.6 & 156.0 & 170.8 & 143.0 \\
\hline Cabernet Sauvignon & 155.4 & 143.0 & 151.8 & 169.0 & 157.8 \\
\hline Merlot & 156.1 & 182.0 & 137.8 & 154.8 & 150.0 \\
\hline Valdepenas & 156.2 & 174.5 & 137.9 & 169.5 & 143.0 \\
\hline Syrah & 157.3 & 158.4 & 154.5 & 166.5 & 150.0 \\
\hline Pinotage & 160.5 & 157.0 & 160.3 & 165.8 & 158.9 \\
\hline Malbec & 161.1 & 157.0 & 150.9 & 165.5 & 170.9 \\
\hline Lemberger & 161.5 & 157.0 & 145.4 & 175.3 & 168.3 \\
\hline Pinot Noir & 161.7 & 166.1 & 156.6 & 173.9 & 151.0 \\
\hline Cabernet Franc & 163.8 & 160.0 & 159.1 & 173.0 & 163.0 \\
\hline Petite Sirah & 164.1 & 134.5 & 161.5 & 187.5 & 165.6 \\
\hline Petit Verdot & 164.8 & 157.0 & 161.9 & 188.0 & 172.5 \\
\hline Primitivo & 165.8 & 173.0 & 154.5 & 173.8 & 162.1 \\
\hline Souzao & 168.2 & 166.0 & 160.3 & 174.6 & 171.6 \\
\hline Grenache & 168.5 & 159.5 & 160.1 & 178.3 & 176.0 \\
\hline Touriga Nacional & 168.9 & 157.0 & 162.5 & 186.3 & 170.0 \\
\hline Zinfandel & 169.6 & 160.0 & 163.0 & 187.3 & 168.3 \\
\hline Carignan & 171.3 & 159.5 & 165.5 & 188.6 & 171.6 \\
\hline Sangiovese & 172.5 & 176.3 & 152.0 & 191.0 & 170.9 \\
\hline Nebbiolo & 176.7 & 166.0 & 167.6 & 195.5 & 177.8 \\
\hline Barbera & 179.2 & 180.4 & 166.8 & 193.8 & 176.0 \\
\hline Avg & 163.0 & 158.8 & 155.8 & 176.1 & 162.0 \\
\hline $\operatorname{MSD}^{\mathrm{x}}$ & & 6.1 & 4.9 & 1.7 & 2.7 \\
\hline \multicolumn{6}{|l|}{ White skin } \\
\hline Orange Muscat & 144.8 & $n e^{w}$ & 133.8 & 156.8 & 143.8 \\
\hline Flora & 148.8 & 143.0 & 134.3 & 153.3 & 145.6 \\
\hline Chardonnay & 153.5 & 161.4 & 144.5 & 161.0 & 147.0 \\
\hline Pinot Gris & 159.3 & 164.4 & 154.1 & 165.3 & 153.6 \\
\hline Muscat of Alexandria & 166.2 & 143.0 & 165.3 & 185.0 & 171.4 \\
\hline Viognier & 168.2 & 167.0 & 161.6 & 180.0 & 164.0 \\
\hline Avg & 156.8 & 159.9 & 148.9 & 166.9 & 154.2 \\
\hline MSD & & 12.4 & 2.3 & 3.8 & 6.5 \\
\hline \multicolumn{6}{|c|}{$P>\mathrm{F}$} \\
\hline \multicolumn{6}{|l|}{ Red skin } \\
\hline Cultivar (CV) & $<0.0001$ & $<0.0001$ & 0.0002 & $<0.0001$ & $<0.0001$ \\
\hline Year $(Y)$ & $<0.0001$ & & & & \\
\hline $\mathrm{CV} \times \mathrm{Y}$ & $<0.0001$ & & & & \\
\hline \multicolumn{6}{|l|}{ White skin } \\
\hline Cultivar (CV) & $<0.0001$ & 0.2412 & 0.0001 & 0.0013 & 0.041 \\
\hline Year $(Y)$ & $<0.0001$ & & & & \\
\hline $\mathrm{CV} \times \mathrm{Y}$ & 0.0043 & & & & \\
\hline
\end{tabular}

${ }^{\mathrm{z}}$ Cultivars within each skin type are listed in order of 4 -year average.

${ }^{y}$ Clonal designations are listed in Table 1.

${ }^{\mathrm{x}}$ Minimum significant difference using Waller-Duncan k-ratio $\leq 0.05$. ${ }^{\mathrm{w}}$ ne $=$ not evaluated. 
and latest in 2005 (DOY 117) (Table $3)$. The 4-year average DOY for bloom and veraison were 164 (160 to 172 ) and 225 (215 to 230 ), and onset each year corresponded inversely with growing season heat unit accumulation. Budbreak DOY varied more among cultivars within a skin color group than between skin color groups, and significant cultivar-byyear interaction indicates that relative differences among cultivars varied from year to year. The earliest cultivars to break bud in at least 3 of 4 years for each color group were: 'Nebbiolo', 'Sangiovese', 'Grenache', 'Cabernet Franc', 'Lemberger', 'Pinotage', 'Merlot', 'Orange Muscat', and 'Chardonnay' (Table 3). The cultivars last to break bud in at least 3 of 4 years were: 'Pinot Meunier', 'Cabernet Sauvignon', 'Carignan', and the white cultivar 'Flora'. 'Nebbiolo', 'Sangiovese', and 'Lemberger' were also found to break bud earlier than 'Cabernet Sauvignon' in Winchester, VA (Wolf and Miller, 2001).

The number of days required between budbreak and harvest (DTHV) to produce fruit with optimum composition for wine production is known to vary by genotype and by growing site environmental conditions. Red cultivars required $7 \mathrm{~d}$ more between budbreak and harvest (163 DTHV) than white cultivars (156 DTHV), but the large range among cultivars within each skin color group (40 DTHV for reds and 29 DTHV for whites) suggests sufficient variability to identify relatively short-season red cultivars as well as longseason white cultivars (Table 4 ). 'Blauer Portugieser' stands out as a relatively short-season (shortest DTHV in at least 3 of 4 years) red cultivar, and 'Viognier' and 'Muscat of Alexandria' were the latest maturing white cultivars. The longest season, red cultivars in at least 3 of 4 years were 'Barbera' and 'Nebbiolo', and the shortest season white cultivars were 'Orange Muscat' and 'Flora'. This long season trait of 'Nebbiolo' was not observed in Winchester, VA (Wolf and Miller, 2001) where its maturity was similar to 'Lemberger' and earlier than 'Cabernet Sauvignon'. Onset of budbreak did not always correspond with earliness. For example, 'Orange Muscat' was early to break bud and short- season. whereas 'Flora' was late to break bud and also short-season. Cultivars that break bud early would be best suited for sites with low spring frost risk and short-season cultivars would be best suited for sites with high risk of late spring and early fall frost events.

Cultivars differed in yield components, vegetative vigor, and harvest SSC (Table 5). All cultivars produced fruit each year and the

Table 5. Yield components, pruning weight, and fruit harvest soluble solids concentration (SSC) of red and white wine grape cultivars at Parma, ID. ${ }^{\mathrm{z}}$

\begin{tabular}{|c|c|c|c|c|}
\hline Cultivar $^{\mathrm{y}}$ & $\begin{array}{c}\text { Yield } \\
(\mathrm{kg} / \text { vine })^{\mathrm{x}}\end{array}$ & $\begin{array}{c}\text { Berry wt } \\
(\mathrm{g})^{\mathrm{x}}\end{array}$ & $\begin{array}{c}\text { Cluster wt } \\
(\mathrm{g})\end{array}$ & SSC (\%) \\
\hline \multicolumn{5}{|l|}{ Red skin } \\
\hline VP & $7.2 \mathrm{a}$ & $1.6 \mathrm{~b}$ & $212.6 \mathrm{abc}$ & $24.0 \mathrm{cdefg}$ \\
\hline PT & $7.1 \mathrm{a}$ & $1.1 \mathrm{ijk}$ & $151.4 \mathrm{defg}$ & 24.3 bcdef \\
\hline CG & $6.7 \mathrm{ab}$ & $1.7 \mathrm{ab}$ & $223.7 \mathrm{ab}$ & $22.9 \mathrm{~h}$ \\
\hline PR & $6.5 \mathrm{abc}$ & $1.6 \mathrm{~b}$ & $207.1 \mathrm{abc}$ & $25.1 \mathrm{~b}$ \\
\hline GR & $6.3 \mathrm{abcd}$ & $1.4 \mathrm{ef}$ & $193.0 \mathrm{abcd}$ & 24.5 bcde \\
\hline SG & $6.3 \mathrm{abcd}$ & $1.5 \mathrm{bcd}$ & 179.5 bcde & $23.5 \mathrm{fgh}$ \\
\hline MA & $6.2 \mathrm{abcd}$ & $1.5 \mathrm{bcd}$ & $116.0 \mathrm{gh}$ & $23.6 \mathrm{efgh}$ \\
\hline BA & 5.9 abcde & $1.8 \mathrm{a}$ & $170.3 \mathrm{cdef}$ & $26.5 \mathrm{a}$ \\
\hline LE & 5.8 abcde & $1.3 \mathrm{fgh}$ & $187.7 \mathrm{abcd}$ & $23.5 \mathrm{fgh}$ \\
\hline TG & 5.6 bcde & $1.1 \mathrm{hij}$ & 134.2 efgh & 24.5 bcde \\
\hline $\mathrm{DL}$ & 5.5 bcde & $1.3 \mathrm{efg}$ & $211.7 \mathrm{abc}$ & $24.9 \mathrm{bc}$ \\
\hline PS & 5.4 bcde & $1.3 \mathrm{fgh}$ & 155.6 defg & 23.79 defgh \\
\hline $\mathrm{NB}$ & 5.2 bcdef & $1.5 \mathrm{cde}$ & $228.7 \mathrm{a}$ & $24.8 \mathrm{bc}$ \\
\hline $\mathrm{CF}$ & $5.1 \mathrm{cdefg}$ & 1.2 ghij & $167.4 \mathrm{cdef}$ & $24.1 \mathrm{cdefg}$ \\
\hline SZ & 4.9 defg & $1.4 \mathrm{def}$ & $127.7 \mathrm{fgh}$ & 24.4 bcdef \\
\hline CS & $4.8 \mathrm{defg}$ & $1.0 \mathrm{kl}$ & $115.3 \mathrm{gh}$ & $23.3 \mathrm{gh}$ \\
\hline $\mathrm{BP}$ & $4.5 \mathrm{efgh}$ & 1.3 fghi & $155.3 \mathrm{efgh}$ & $21.1 \mathrm{i}$ \\
\hline $\mathrm{ME}$ & $4.5 \mathrm{efgh}$ & $1.1 \mathrm{jk}$ & $110.6 \mathrm{gh}$ & 24.2 bcdef \\
\hline $\mathrm{ZN}$ & 4.4 efgh & $1.6 \mathrm{bc}$ & $209.4 \mathrm{abc}$ & $26.0 \mathrm{a}$ \\
\hline SY & $3.7 \mathrm{fgh}$ & $1.2 \mathrm{ghij}$ & 136.0 efgh & 24.3 bcdef \\
\hline $\mathrm{MN}$ & $3.6 \mathrm{gh}$ & 1.2 ghij & $97.7 \mathrm{~h}$ & $23.8 \mathrm{defg}$ \\
\hline $\mathrm{PN}$ & $3.1 \mathrm{ih}$ & $1.1 \mathrm{ijk}$ & $98.1 \mathrm{~h}$ & $23.7 \mathrm{efgh}$ \\
\hline PV & $1.9 \mathrm{i}$ & 0.91 & $38.1 \mathrm{i}$ & $24.7 \mathrm{bcd}$ \\
\hline \multicolumn{5}{|l|}{ White skin } \\
\hline Muscat of Alexandria & $7.9 \mathrm{a}$ & $3.6 \mathrm{a}$ & $182.3 \mathrm{a}$ & $23.5 \mathrm{a}$ \\
\hline Pinot Gris & $6.5 \mathrm{ab}$ & $1.1 \mathrm{c}$ & $127.4 \mathrm{bc}$ & $23.7 \mathrm{a}$ \\
\hline Orange Muscat & $5.5 \mathrm{bc}$ & $1.9 \mathrm{~b}$ & $152.2 \mathrm{~b}$ & $23.6 \mathrm{a}$ \\
\hline Viognier & $5.0 \mathrm{bc}$ & $0.9 \mathrm{e}$ & $109.1 \mathrm{~cd}$ & $24.3 \mathrm{a}$ \\
\hline Chardonnay & $4.7 \mathrm{bc}$ & $1.0 \mathrm{~d}$ & $106.1 \mathrm{~cd}$ & $23.4 \mathrm{a}$ \\
\hline \multirow[t]{2}{*}{ Flora } & $4.5 \mathrm{c}$ & $0.9 \mathrm{e}$ & $97.5 \mathrm{~d}$ & $24.3 \mathrm{a}$ \\
\hline & \multicolumn{2}{|c|}{$P>\mathrm{F}$} & & \\
\hline \multicolumn{5}{|l|}{ Red skin } \\
\hline Cultivar (CV) & 0.0022 & $<0.0001$ & $<0.0001$ & $<0.0001$ \\
\hline Year $(\mathrm{Y})$ & $<0.0001$ & 0.0004 & 0.0013 & 0.1565 \\
\hline $\mathrm{CV} \times \mathrm{Y}$ & 0.6251 & 0.5874 & 0.1687 & 0.3493 \\
\hline 2002 & $7.0 \mathrm{a}$ & $1.2 \mathrm{c}$ & $216.3 \mathrm{a}$ & $24.1 \mathrm{a}$ \\
\hline 2003 & $5.2 \mathrm{~b}$ & $1.4 \mathrm{ab}$ & $162.9 \mathrm{~b}$ & $24.1 \mathrm{a}$ \\
\hline 2004 & $5.3 \mathrm{~b}$ & $1.3 \mathrm{~b}$ & $151.1 \mathrm{bc}$ & $24.1 \mathrm{a}$ \\
\hline 2005 & $4.3 \mathrm{c}$ & $1.4 \mathrm{a}$ & $141.6 \mathrm{c}$ & $24.3 \mathrm{a}$ \\
\hline \multicolumn{5}{|l|}{ White skin } \\
\hline Cultivar (CV) & 0.0609 & $<0.0001$ & 0.0245 & 0.8717 \\
\hline Year $(\mathrm{Y})$ & 0.2816 & 0.5063 & 0.9010 & 0.0400 \\
\hline $\mathrm{CV} \times \mathrm{Y}$ & 0.5914 & 0.0852 & 0.4754 & 0.0784 \\
\hline 2002 & $8.0 \mathrm{a}$ & $0.8 \mathrm{~b}$ & $126.1 \mathrm{a}$ & $22.7 \mathrm{a}$ \\
\hline 2003 & $4.7 \mathrm{c}$ & $1.5 \mathrm{a}$ & $126.6 \mathrm{a}$ & $24.3 \mathrm{a}$ \\
\hline 2004 & $6.4 \mathrm{~b}$ & $1.5 \mathrm{a}$ & $124.9 \mathrm{a}$ & $23.5 \mathrm{ab}$ \\
\hline 2005 & $4.7 \mathrm{c}$ & $1.5 \mathrm{a}$ & $118.3 \mathrm{a}$ & $24.0 \mathrm{a}$ \\
\hline
\end{tabular}

${ }^{\mathrm{z}}$ Cultivars within each skin type are listed in order of yield. Unless labeled otherwise, values are average of years 2002-2005.

${ }^{y}$ Acronyms and clonal designations are listed in Table 1.

${ }^{\mathrm{x}} 1 \mathrm{~kg}=2.2046 \mathrm{lb}, 1 \mathrm{~g}=0.0353 \mathrm{oz}$ 
4-year average yield ranged from $4.3 \mathrm{~kg}$ /vine in 2005 to $7.0 \mathrm{~kg}$ /vine in 2002. The red cultivars 'Zinfandel', 'Petit Verdot', and 'Souzao' produced the least amount of fruit per vine and 'Valdepenas', 'Malbec', 'Pinotage', and 'Carignan' produced the most. The ratio of yield to pruning weight is a measure of vine balance between vegetative and reproductive growth. The yield to pruning weight ratio for most cultivars was within the recommended range of 5 to 10 ; however, 'Petit Verdot' was 4.6, and 'Dolcetto', 'Grenache', 'Pinotage', 'Pinot Gris', 'Flora', and 'Muscat of Alexandria' were greater than 10 . Berry weight is an index of size and red wines made from smaller berries are thought to have more favorable character (Kennedy, 2002). The weight of berries and clusters varied among cultivars with 'Valdepenas', 'Carignan', 'Primitivo', 'Zinfandel', and 'Muscat of Alexandria' having the largest and 'Petit Verdot' the smallest.

Must SSC, TA, and $\mathrm{pH}$ are common indicators of fruit maturity and known to vary by genotype and environment. Cultivar differences in harvest SSC were consistent from year to year (Table 5), but TA (Table 6) and $\mathrm{pH}$ (Table 7) varied seasonally. The 4 -year average must SSC at harvest of all cultivars was $24 \%$, but 'Blauer Portugieser' was harvested at $21 \%$ SSC because must TA was below and $\mathrm{pH}$ was above target levels. 'Barbera' was harvested at higher than $24 \%$ SSC because its level of TA was higher and $\mathrm{pH}$ lower than target. Growing season impacted the TA and $\mathrm{pH}$ of red more than white cultivars, and the relative difference among red cultivars varied seasonally. The average harvest $\mathrm{pH}$ of white cultivars was 3.4 and was highest in 2003 , the warmest growing season.

Evaluation of wine grape cultivar performance requires interpretation of fruit maturity in relation to vine balance. The ratio of SSC to TA is an index of quality for wine production and higher than optimum values suggest less desirable, advanced maturity. The optimum ratio of SSC to TA ranged from 2.7 to 3.5 for wines produced from 'Thompson Seedless' (Ough and Alley, 1970). The optimum ratio of SSC to TA for this study, based on harvest criteria, was
3.4 for red and 3.0 for white cultivars. Calculated values for fruit maturity and yield to pruning weight averaged over multiple growing seasons were used to group cultivar performance into one of three categories with three outliers ['Blauer Portugieser', 'Muscat of Alexandria', and 'Petit Verdot'
(Fig. 1)]. Cultivars with closest to optimum vine balance and fruit maturity are assumed best suited to the Parma growing site. Although not part of the present study, one can speculate that cultivars with advanced fruit maturity under optimum or higher than optimum vine balance

Table 6. Titratable acidity of must at harvest for red and white wine grape cultivars at Parma, ID. ${ }^{\mathrm{z}}$

\begin{tabular}{|c|c|c|c|c|c|}
\hline \multirow[b]{2}{*}{ Cultivar $^{\mathrm{y}}$} & \multicolumn{5}{|c|}{ Titratable acidity $\left(\mathrm{g} \cdot \mathrm{L}^{-1}\right)^{\mathrm{x}}$} \\
\hline & Avg 2002-2005 & 2002 & 2003 & 2004 & 2005 \\
\hline \multicolumn{6}{|l|}{ Red skin } \\
\hline Blauer Portugieser & 3.48 & 5.00 & 3.75 & 2.48 & 3.83 \\
\hline Sangiovese & 4.47 & 4.75 & 4.10 & 4.43 & 4.75 \\
\hline Dolcetto & 4.94 & 5.95 & 4.93 & 3.70 & 5.70 \\
\hline Cabernet Franc & 4.99 & 4.60 & 4.60 & 4.80 & 5.68 \\
\hline Merlot & 5.02 & 5.38 & 6.15 & 3.90 & 4.65 \\
\hline Cabernet Sauvignon & 5.06 & 5.40 & 5.45 & 3.78 & 5.78 \\
\hline Pinot Meunier & 5.31 & $n e^{w}$ & 5.40 & 4.18 & 6.35 \\
\hline Syrah & 5.35 & 5.10 & 4.35 & 5.58 & 6.20 \\
\hline Pinotage & 5.56 & 6.10 & 5.56 & 5.43 & 5.58 \\
\hline Touriga Nacional & 5.57 & 6.10 & 5.60 & 5.03 & 5.95 \\
\hline Valdepenas & 5.64 & 4.75 & 5.90 & 5.53 & 5.93 \\
\hline Pinot Noir & 5.66 & ne & 4.97 & 5.20 & 6.53 \\
\hline Grenache & 6.01 & 6.15 & 6.35 & 3.75 & 7.88 \\
\hline Primitivo & 6.06 & 6.00 & 7.00 & 4.18 & 7.03 \\
\hline Lemberger & 6.07 & 8.30 & 6.65 & 4.58 & 5.88 \\
\hline Malbec & 6.34 & 5.63 & 6.35 & 7.30 & 6.10 \\
\hline Petite Sirah & 6.36 & 6.20 & 5.80 & 6.05 & 7.33 \\
\hline Zinfandel & 6.40 & 5.50 & 5.48 & 5.83 & 8.13 \\
\hline Souzao & 7.44 & 8.50 & 6.15 & 5.93 & 9.20 \\
\hline Carignan & 7.96 & ne & 7.65 & 6.05 & 10.20 \\
\hline Nebbiolo & 8.01 & 7.60 & 7.50 & 6.05 & 10.70 \\
\hline Barbera & 8.98 & 13.10 & 7.88 & 7.22 & 9.80 \\
\hline Petit Verdot & 10.29 & ne & 11.75 & 6.10 & 13.03 \\
\hline Avg & 6.13 & 6.32 & 6.06 & 5.09 & 7.05 \\
\hline $\mathrm{MSD}^{\mathrm{v}}$ & & 2.26 & 2.49 & 0.69 & 1.25 \\
\hline \multicolumn{6}{|l|}{ White skin } \\
\hline Pinot Gris & 5.67 & 6.70 & 4.70 & 6.03 & 6.03 \\
\hline Flora & 5.92 & 5.60 & 5.68 & 5.18 & 6.98 \\
\hline Orange Muscat & 6.23 & ne & 6.60 & 4.98 & 7.13 \\
\hline Muscat of Alexandria & 6.68 & ne & 6.17 & 5.97 & 7.60 \\
\hline Chardonnay & 6.76 & 7.50 & 6.53 & 5.78 & 7.80 \\
\hline Viognier & 6.99 & 6.05 & 6.10 & 7.08 & 8.28 \\
\hline Avg & 6.38 & 6.46 & 5.96 & 5.83 & 7.30 \\
\hline MSD & & & 1.44 & 1.19 & 1.12 \\
\hline \multicolumn{6}{|c|}{$P>\mathrm{F}$} \\
\hline \multicolumn{6}{|l|}{ Red skin } \\
\hline Cultivar (CV) & $<0.0001$ & 0.0390 & 0.0077 & $<0.0001$ & $<0.0001$ \\
\hline Year $(Y)$ & $<0.0001$ & & & & \\
\hline $\mathrm{CV} \times \mathrm{Y}$ & 0.0165 & & & & \\
\hline \multicolumn{6}{|l|}{ White skin } \\
\hline Cultivar (CV) & 0.0223 & & 0.2705 & 0.5120 & 0.0999 \\
\hline Year $(\mathrm{Y})$ & 0.1620 & & & & \\
\hline $\mathrm{CV} \times \mathrm{Y}$ & 0.8827 & & & & \\
\hline
\end{tabular}


Table 7. Must $\mathrm{pH}$ at harvest for red and white wine grape cultivars at Parma, ID. ${ }^{\mathrm{z}}$

\begin{tabular}{|c|c|c|c|c|c|}
\hline \multirow[b]{2}{*}{ Cultivar $^{\mathrm{y}}$} & \multicolumn{5}{|c|}{ Must pH } \\
\hline & Avg 2002-2005 & 2002 & 2003 & 2004 & 2005 \\
\hline \multicolumn{6}{|l|}{ Red skin } \\
\hline Barbera & 3.27 & 3.04 & 3.27 & 3.39 & 3.27 \\
\hline Nebbiolo & 3.33 & 3.13 & 3.31 & 3.56 & 3.23 \\
\hline Souzao & 3.33 & 3.13 & 3.33 & 3.61 & 3.25 \\
\hline Petit Verdot & 3.38 & $n e^{x}$ & 3.26 & 3.67 & 3.18 \\
\hline Lemberger & 3.38 & 3.23 & 3.12 & 3.61 & 3.50 \\
\hline Petite Sirah & 3.41 & 3.27 & 3.49 & 3.49 & 3.34 \\
\hline Carignan & 3.43 & ne & 3.34 & 3.65 & 3.30 \\
\hline Grenache & 3.46 & 3.36 & 3.24 & 3.90 & 3.30 \\
\hline Malbec & 3.52 & 3.53 & 3.49 & 3.41 & 3.68 \\
\hline Primitivo & 3.55 & 3.77 & 3.37 & 3.87 & 3.39 \\
\hline Dolcetto & 3.55 & 3.37 & 3.41 & 3.81 & 3.55 \\
\hline Zinfandel & 3.57 & 3.73 & 3.59 & 3.67 & 3.43 \\
\hline Cabernet Sauvignon & 3.58 & 3.58 & 3.37 & 3.91 & 3.47 \\
\hline Pinot Noir & 3.59 & ne & 3.51 & 3.81 & 3.49 \\
\hline Cabernet Franc & 3.60 & 3.84 & 3.48 & 3.68 & 3.57 \\
\hline Pinotage & 3.60 & 3.87 & 3.48 & 3.62 & 3.61 \\
\hline Touriga Nacional & 3.61 & 3.61 & 3.45 & 3.76 & 3.62 \\
\hline Syrah & 3.62 & 3.97 & 3.55 & 3.67 & 3.56 \\
\hline Sangiovese & 3.63 & 3.53 & 3.59 & 3.69 & 3.65 \\
\hline Valdepenas & 3.65 & 3.96 & 3.49 & 3.72 & 3.62 \\
\hline Pinot Meunier & 3.67 & ne & 3.46 & 4.03 & 3.53 \\
\hline Merlot & 3.70 & 3.81 & 3.58 & 3.71 & 3.71 \\
\hline Blauer Portugieser & 3.89 & 3.95 & 3.72 & 4.09 & 3.86 \\
\hline Avg & 3.54 & 3.56 & 3.43 & 3.71 & 3.48 \\
\hline $\mathrm{MSD}^{\mathrm{w}}$ & & 0.39 & 0.29 & 0.15 & 0.12 \\
\hline \multicolumn{6}{|l|}{ White skin } \\
\hline Flora & 3.31 & 3.51 & 3.57 & 3.14 & 3.21 \\
\hline Viognier & 3.32 & 3.33 & 3.54 & 3.31 & 3.12 \\
\hline Chardonnay & 3.33 & 3.51 & 3.47 & 3.18 & 3.29 \\
\hline Muscat of Alexandria & 3.36 & ne & 3.47 & 3.35 & 3.30 \\
\hline Pinot Gris & 3.40 & 3.48 & 3.51 & 3.33 & 3.37 \\
\hline Orange Muscat & 3.40 & ne & 3.46 & 3.31 & 3.43 \\
\hline Avg & 3.35 & 3.46 & 3.50 & 3.27 & 3.29 \\
\hline MSD & & & 0.11 & 0.11 & 0.15 \\
\hline \multicolumn{6}{|c|}{$P>\mathrm{F}$} \\
\hline \multicolumn{6}{|l|}{ Red skin } \\
\hline Cultivar (CV) & $<0.0001$ & 0.1095 & 0.1114 & 0.0055 & 0.0010 \\
\hline Year $(Y)$ & $<0.0001$ & & & & \\
\hline $\mathrm{CV} \times \mathrm{Y}$ & 0.0296 & & & & \\
\hline \multicolumn{6}{|l|}{ White skin } \\
\hline Cultivar (CV) & 0.3474 & & 0.4215 & 0.1845 & 0.1591 \\
\hline Year $(Y)$ & 0.0003 & & & & \\
\hline $\mathrm{CV} \times \mathrm{Y}$ & 0.0644 & & & & \\
\hline
\end{tabular}

${ }^{z}$ Cultivars within each skin type are listed in order of 2002-2005 average value.

yClonal designations are listed in Table 1 .

${ }^{\mathrm{x}}$ ne $=$ not evaluated.

"Minimum significant difference using Waller-Duncan k-ratio $\leq 0.05$.

may achieve better fruit composition if harvested at a SSC lower than $24 \%$, cropped at a higher yield to pruning weight ratio, or grown in a cooler site. The advanced fruit maturity of 'Blauer Portugieser' when harvested at $21 \%$ SSC (Table 5 ) at optimum vine balance suggests that this cultivar is better suited to a cooler growing site.
The high yield to pruning weight ratio of 'Muscat of Alexandria' is partly the result of large cluster and berry size but may also be indicative of dormant season desiccation and sensitivity to cold injury. The clone of 'Petit Verdot' evaluated in this trial is known for low productivity. More productive clones of this cultivar are available but were not evaluated in this study.

Data from this study as well as other cultivar evaluation trials can be used to further guide cultivar selection within each of the groupings depicted in Figure 1. 'Malbec', 'Petite Sirah', and 'Chardonnay' were reported best suited to California Climatic Region II (Amerine and Winkler, 1944), which is similar to the Parma site. 'Malbec' and 'Petite Sirah' produced well in Prosser, WA (Nagel and Spayd, 1990) and 'Petite Sirah' produced well yet was sensitive to cold injury in Grand Junction, CO (Hamman, 1993). Under similar bud numbers, 'Malbec' yielded more than twice the amount of fruit as 'Souzao' (Table 5), suggesting higher potential for economic return. 'Chardonnay' was rated cold-hardy (Ahmedullah, 1985; Hamman, 1993; Wolf and Warren, 2000) and produced good quality fruit over a wide range of growing conditions, including Prosser, WA (Powers et al., 1992), Grand Junction, CO (Hamman, 1993), Winchester, VA (Wolf and Warren, 2000), Reno, NV (Evans et al., 2005), and British Columbia, Canada (Reynolds et al., 2004). 'Barbera', 'Nebbiolo', and 'Carignan' were reported best suited for California Climatic Region III or IV (Amerine and Winkler, 1944), which is warmer than the Parma site, and our results support this classification. The high acidity of these cultivars, despite higher than average heat unit accumulation during the years of this study, suggests that these cultivars may produce better balanced fruit when grown in a site warmer than Parma. 'Barbera' was reported as cold-hardy and 'Nebbiolo' coldsensitive in Grand Junction, CO (Hamman, 1993) and Winchester, VA (Wolf and Miller, 2001). Basal bud infertility was observed in 'Nebbiolo' (Wolf and Miller, 2001). 'Viognier' grown in a site $\approx 250$ GDDs warmer than Parma (Winchester, VA) matured $11 \mathrm{~d}$ earlier but had higher than optimum levels of $\mathrm{pH}$ (Wolf and Warren, 2000), suggesting it may be better suited to a cooler site. 'Viognier' was reported as cold-hardy but had a high incidence of basal bud necrosis (Wolf and Warren, 2000). Pruning weight was not collected in this study for 'Orange Muscat', but its ratio of SSC to TA was 3.8, 


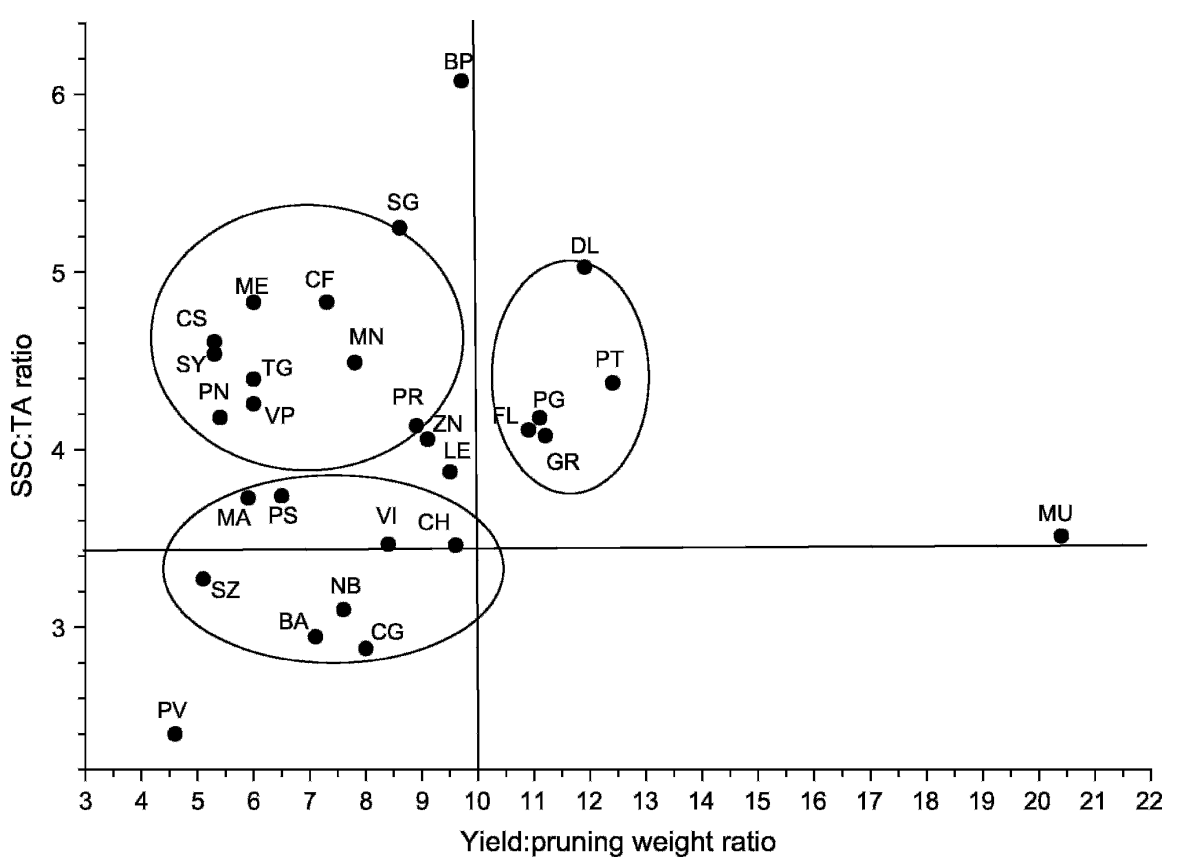

Fig. 1. Four-year average values for harvest fruit maturity [ratio of soluble solids concentration (SSC) to titratable acidity (TA)] and yield to pruning weight ratio of red and white cultivars evaluated at Parma, ID. Optimum values for vine balance and fruit maturity are depicted as lines on each axis. Cultivar acronyms are listed in Table 1.

suggesting inclusion in this group. 'Orange Muscat' produced highquality wine in Prosser, WA (Nagel and Spayd, 1990) and was rated superior to 'Muscat of Alexandria' (Amerine and Winkler, 1944).

The majority of cultivars in this study had optimum vine balance with advanced fruit maturity. 'Lemberger', 'Zinfandel', and 'Primitivo' had closest to optimum maturity. 'Lemberger' is reported best suited to California Climatic Regions I and II (Amerine and Winkler, 1944), which is cooler or similar to the Parma site. 'Lemberger' was found to be cold-hardy in Prosser, WA (Ahmedullah, 1985), Grand Junction, CO (Hamman, 1993), and Winchester, VA (Wolf and Miller, 2001) and produced fruit in Reno, NV (Evans et al., 2005). 'Zinfandel' is best suited to California Climatic Regions II and III (Amerine and Winkler, 1944), which is similar to the Parma site. 'Primitivo', a selection from the same cultivar as 'Zinfandel', was reported to have earlier fruit maturity and superior production attributes than 'Zinfandel' in the central San Joaquin Valley (Fidelibus, 2005). 'Zinfandel' was found to be cold-sensitive in Grand Junction, CO (Hamman, 1993) and produced mediocre quality wine in Prosser, WA (Nagel and Spayd, 1990). In this study under similar bud number, 'Primitivo' yielded twice the amount of fruit as 'Zinfandel' (Table 5), suggesting greater potential economic return. The Bordeaux cultivars 'Cabernet Sauvignon', 'Merlot', and 'Cabernet Franc' yielded similarly in this study and performed well in Grand Junction, CO (Hamman, 1993). 'Cabernet Franc' produced fruit in Reno, NV (Evans et al., 2005), and 'Merlot' performed well in Napa Valley, CA (Benz et al., 2006), the Okanagan Valley, British Columbia, Canada (Reynolds et al., 2004), and Prosser, WA (Powers et al., 1992). Mild cold injury has been observed on 'Cabernet Sauvignon' (Wolf and Miller, 2001) and 'Merlot' (Ahmedullah, 1985; Hamman, 1993). 'Syrah' performed well in Grand Junction, CO, had inconsistent quality in Winchester, VA (Wolf and Miller, 2001), and was sensitive to cold injury (Hamman, 1993; Wolf and Miller, 2001). 'Pinot Noir' is best suited for California Climatic Region I (Amerine and Winkler, 1944), which is cooler than the Parma site. 'Pinot Noir' has been evaluated in Prosser, WA (Ahmedullah, 1985), the Willamette Valley, OR
(Castagnoli and Vasconcelos, 2006), Reno, NV (Evans et al., 2005), Los Carneros, CA (Mercado-Martin et al., 2006), and the Okanagon Valley (Reynolds et al., 2004) and is reported as more cold-tolerant than the Bordeaux cultivars (Ahmedullah, 1985; Hamman, 1993). 'Sangiovese' and 'Valdepenas' produced fruit of mediocre quality and were less coldhardy than 'Cabernet Sauvignon' in Winchester, VA (Wolf and Miller, 2001). No comparative trial results were found in the literature for 'Touriga Nacional'.

Three red ('Grenache', 'Pinotage', and 'Dolcetto') and two white ('Flora' and 'Pinot Gris') cultivars produced fruit with advanced maturity when cropped at higher than optimum vine balance. 'Grenache' has been reported best suited for California Climatic Regions I and II, which is cooler or similar to the Parma site, and to have low heat tolerance (Amerine and Winkler, 1944). 'Grenache' was rated cold-hardy (Ahmedullah, 1985) in Prosser, WA. Comparative data were not available for 'Dolcetto' or 'Pinotage'. The white cultivars 'Flora' and 'Pinot Gris' produced high-quality wine (Nagel and Spayd, 1990) and 'Pinot Gris' produced fruit in Reno, NV (Evans et al., 2005). In this study, 'Pinot Gris' yielded more fruit than 'Flora' (Table 5), suggesting higher potential economic return.

\section{Conclusions and grower benefits}

Matching germplasm to site location is a fundamental viticultural practice to enhance yield and fruit quality. Results from this study describe the viticultural performance of a diverse collection of red and white wine grape cultivars as a guide to aid cultivar selection for planting sites. Knowledge of heat unit accumulation and freeze events in an intended new planting site is a critical prerequisite for using the results from this research. The vines evaluated in this study were planted after the last major cold event (Feb. 1989) where temperatures reached a minimum of $-30{ }^{\circ} \mathrm{C}$. Future temperatures may not be as moderate as the years observed during this study and reported cold-hardiness data from other trial sites should be considered. 


\section{Literature cited}

Ahmedullah, M. 1985. Site selection for grapes in eastern Washington. Ext. Bul. 1358, Washington State Univ., Pullman.

Amerine, M.A. and A.J. Winkler. 1944. Composition and quality of musts and wines of California grapes. Hilgardia 15:493-673.

Benz, M.J., M.M. Anderson, M.A. Williams, K. Barnhisel, and J.A. Wolpert. 2006. Viticultural performance of five Merlot clones in Oakville, Napa Valley. Amer. J. Enol. Viticult. 57:233-237.

Castagnoli, S. and M.C. Vasconcelos. 2006. Field performance of 20 'Pinot Noir' clones in the Willamette Valley of Oregon. HortTechnology 16:153-161.

Clore, W.J., C.W. Nagel, and G.H. Carter. 1976. Ten years of grape variety response and winemaking trials in Washington. Ext. Bul. 0823, Washington State Univ., Pullman.

Coombe, B.G. 1995. Growth stages of the grapevine. Aust. J. Grape Wine Res. $1: 100-110$.

Desert Research Institute. 2006. Western Regional Climate Center. 15 Nov. 2006. <http://www.wrcc.dri.edu/cgi-bin/ cliMAIN.pl?id6844>.

Evans, J., E.A.R. Tattersall, W. Johnson, and G.R. Cramer. 2005. Towards wine grape (Vitis vinifera) vineyard establishment in northern Nevada. Varietal studies in a dry desert climate. Nevada Agr. Ext. Serv. Publ. 51055382, Reno.

Fallahi, E., B. Fallahi, B. Shafii, and J.C. Stark. 2005. Performance of six wine grapes under southwest Idaho environmental conditions. Small Fruits Rev. 4:77-85.

Fallahi, E., B. Shafii, B. Fallahi, J.C. Stark, and A.L. Engel. 2004. Yield, quality attributes, and degree day requirements of various wine grapes under climatic conditions of intermountain west region. J. Amer. Pomol. Soc. 58: $158-162$

Fegan, P. 2003. The vineyard handbook: Appellations, maps and statistics. Chicago Wine School, Chicago.
Fidelibus, M.W. 2005. Performance of Zinfandel and Primitivo grapevine selections in the central San Joaquin Valley, California. Amer. J. Enol. Viticult. 56:284-286.

Gillerman, V.S., D. Wilkins, K. Shellie, and R. Bitner. 2006. Geology and wine 11: Terroir of the Western Snake River Plain, Idaho. GeoScience Can. 33:3748.

Hamman, R. 1993. Wine grape performance of 32 cultivars in western Colorado 1982-1986. Fruit Var. J. 47:59-63.

Johnson, H. 1994. The world atlas of wine. Simon \& Schuster, New York.

Kaps, M.L. and M.B. Odneal. 2001. Grape cultivar performance in the Missouri Ozark region. J. Amer. Pomol. Soc. $55: 34-44$

Kennedy, J. 2002. Understanding grape berry development. Practical Winery Vineyard July/August:14-23.

Mercado-Martin, G.I., J.A. Wolpert, and R.J. Smith. 2006. Viticultural evaluation of eleven clones and two field selections of Pinot Noir grown for production of sparkling wine in Los Carneros, California. Amer. J. Enol. Viticult. 57:371-376.

Nagel, C.W. and S.E. Spayd. 1990. Yield and enological characteristics of grape cultivars in central Washington 1974 1987. Ext. Bul. 1591, Washington State Univ., Pullman.

The Northwest Berry and Grape Information Network. 2004. Online phenology and degree-day models for agricultural decision making in the Pacific Northwest. 15 Nov. 2006. <http://ippc2.orst.edu/ cgi-bin/ddmodel.pl>.

Ough, C.S. and C.J. Alley. 1970. Effect of 'Thompson Seedless' grape maturity on wine composition and quality. Amer. J. Enol. Viticult. 21:78-84.

Powers, J.R., C.W. Nagel, E.L. Proebsting, and M. Ahmedullah. 1992. Evaluation of selected vineyard sites in Washington State. Coop. Ext. Bul 1707, Washington State Univ., Pullman.
Reynolds, A.G., M. Cliff, D.A. Wardle, and M. King. 2004. Evaluation of winegrapes in British Columbia: New cultivars and selections from Germany and Hungary. HortTechnology 14 : $420-436$.

Shellie, K.C. 2006. Vine and berry response of Merlot (Vitis vinifera) to differential water stress. Amer. J. Enol. Viticult. 57:514-518.

U.S. Dept. Agr. 1972. Soil survey of Canyon Area, Idaho. U.S. Dept. Agr., Soil Conservation Service. Superintendent of Documents, U.S. Govt. Printing Office, Washington, DC.

U.S. Dept. Agr. 2007. Final Idaho fruit tree census 06.pub. 3 Mar. 2007. <http:// search.usda.gov/search? q=idaho+ tree + fruit + survey \& client $=$ usda \& site $=$ NASS_MAIN\&proxystylesheet $=$ NASS\& output=xml_no_dtd\&access $=$ p\&mode $=$ simple\&as_occt=any\&num $=10>$.

U.S. Dept. Interior. 2006. Agrimet-The Pacific Northwest cooperative agricultural network. 15 Nov. 2006. <http// www.usbr.gov/pn/grimet/yearrpt. html>.

Watson, J. (ed.). 1999. Growing grapes in eastern Washington: Proceedings from the 1998 Washington State University shortcourse for establishing a vineyard and producing grapes. Good Fruit Grower, Yakima, WA.

Weaver, R.J. 1976. Grape growing. Wiley, New York.

Winkler, A.J., J.A. Cook, W.M. Kliewer, and L.A. Lider. 1974. General viticulture. University of California Press, Los Angeles, CA.

Wolf, T.K. and M.K. Miller. 2001. Crop yield, fruit quality, and winter injury of 12 red-fruited wine grape cultivars in northern Virginia. J. Amer. Pomol. Soc. 55:241-250

Wolf, T.K. and M.K. Warren. 2000. Crop yield, grape quality, and winter injury of eight wine grape cultivars in northern Virginia. J. Amer. Pomol. Soc. 54:34-43. 